\title{
ENGAGEMENT WITH LANGUAGE: A POTENTIAL CONSTRUCT IN PEER INTERACTION RESEARCH
}

\author{
Nguyen Thu Hien* \\ Faculty of English Language Teacher Education, \\ VNU University of Languages and International Studies, \\ Pham Van Dong, Cau Giay, Hanoi, Vietnam \\ Received 28 July 2019 \\ Revised 15 October 2019; Accepted 22 December 2019
}

\begin{abstract}
Language learners spend a considerable amount of time interacting with other learners in both second and foreign language classrooms. The idea that peer interaction has increasingly been considered a context for language learning has been matched by a growing body of research examining different aspects of peer talk. Previous literature has provided important insights into various aspects of learnerlearner interaction including the provision of interactional feedback, output production, modifications in the process of negotiation for meaning, the attention paid by language learners to language forms, as well as the collaboration among learners in the construction of the language knowledge. However, no comprehensive framework has been established to enable the integration of various features. Recently, engagement with language, proposed by Svalberg (2009) has emerged as a more encompassing concept which integrates cognitive, social and affective aspects of learner-learner interaction. This paper aims to propose this newly emerged construct as a potential for research into peer interaction among language learners.
\end{abstract}

Keywords: engagement with language, peer interaction, cognitive, social, affective

\section{Introduction}

Interaction in second language (L2) teaching and learning has attracted increasing research interest over the last several decades. Its origins can be traced back to the 1970s, when researchers became interested in the ways native speakers simplified their speech for learners to understand - foreigner talk (e.g., Ferguson, 1971, 1975). From the mid1970s, researchers began to credit more importance to the role of dialogue in language learning. For example, Wagner-Gough and Hatch (1975, p. 307) argued that researchers needed to investigate "the relationship

Tel: 84-963261175

Email: thuhien@vnu.edu.vn between language and communication if we are looking for explanations of the learning process", and Hatch (1978, p. 404) claimed interaction as the site for L2 learning, that "one learns how to do conversation, one learns how to interact verbally, and out of this interaction syntactic structures are developed". In many L2 teaching and learning contexts, the majority of opportunities for L2 learners to engage in communicative discussions occur with other peers (Adams, Nuevo, \& Egi, 2011). A recent review of peer interaction studies by Kang (2015) shows that peer interaction benefits L2 learners by "creating opportunities to produce and modify output, receive feedback, and engage in collaborative dialogue" (p. 85). This paper focuses on literature on peer interaction and introduces the concept of engagement 
with language as a potential construct in L2 research.

\section{Peer interaction in second language teaching and learning}

\subsection{Benefits of peer interaction}

To date, a growing body of research has focused on examining the relationship between peer interaction and L2 learning, and has often produced positive results (Adams, 2007; Mackey, 2006; McDonough, 2004; Philp \& Iwashita, 2013; Sato \& Lyster, 2007, 2012). For example, the findings of Philp and Iwashita (2013) show that practicing using language during peer interaction benefits the learning process. This is because when learners actively participate in the conversation, they tend to pay more attention to form and meaning connections, and try to use the target language to express their ideas. This affords opportunities for learners to test out and modify their erroneous utterances. Adams (2007) also shows evidence of the learning of L2 forms as a result of feedback provided by learners in the post-tests, based on the feedback of learners.

With regards to its benefits for language development, peer interaction has been found to outweigh the interaction between the teacher and the learner, and even of that between the native speaker and the learner in certain aspects. Research shows that students performed better when working in small groups than in a teacher-fronted classroom in terms of both quantity and quality of language produced (Doughty \& Pica, 1986; Long, Adams, McLean, \& Castanos, 1976), and that a more significant amount of negotiation of content was evident in a small group discussion than in a teacher-led discussion (Rulon \& McCreary, 1986). Comparing interaction between the learner and the native speaker with peer interaction, interactions among language learners were found to provide more elicitation of feedback than native speakers (Sato \& Lyster, 2007), give their peers more opportunities to incorporate feedback than native speakers (Bruton \& Samuda, 1980; Mackey, Oliver, \& Leeman, 2003) and they modified their utterances more often while interacting with other learners than with native speakers (Fernández Dobao, 2012; McDonough, 2004). In addition, peer interaction language learners tend to pay their attention to language features of the target language more often than when they interact with the teacher or the native speaker (Sato \& Ballinger, 2016). This is because learners may feel more comfortable when working with other peers and they have more time to try out their language use (Sato, 2007; Sato \& Lyster, 2007). As such, learner-learner interaction is a useful L2 learning context that complements teacher-learner interaction.

Peer interaction has been found to have positive impacts on second language learning as it affords learners with the chance to communicate in the target language. Peer interaction is often investigated from either interactionist or socio-cultural approaches, and covers aspects such as interactional feedback, attention paid to the target language, and support among learners.

\subsection{Peer interaction from interactionist perspective}

The interactionist approach, also called the interaction approach (Gass \& Mackey, 2007; Mackey, Abbuhl, \& Gass, 2012), was formed based on hypotheses on input, interaction and output. International feedback has been one of the major foci of peer talk research using the interactionist approach. Typically, 
learners provide interactional feedback and solicit modifications and adjustment through a variety of strategies. These range from implicit feedback such as recasts (i.e., operationalized as target-like reformulations of the non-targetlike utterances retaining the central meaning of the original utterance), confirmation checks (i.e., expressions to check whether the previous utterance is correctly understood), comprehension checks (i.e., strategies that check whether the interlocutor understands what is being said), clarification requests (i.e., expressions to clarify the previously heard utterance), to more explicit types of feedback such as correction or metalinguistic feedback (i.e., explanation which points out the mistakes) (Mackey, 2007). Research has shown a positive relationship between feedback provision and language development (e.g., Adams, 2007; Egi, 2007; Mackey, 2006). For example, Adams' (2007) findings show that about $60 \%$ of learners' feedback episodes promoted their learning of linguistic issues.

The provision of interactional feedback also reveals the nature and impact of learners' attention paid to different aspects of the target language, such as vocabulary, grammar or pronunciation (e.g., Fujii \& Mackey, 2009; Mackey, 2006; Mackey, Philp, Egi, Fujii, \& Tatsumi, 2002; Philp, 2003). Mackey (2006) found that learners' noticing of feedback concerning target language features had a positive influence on their language development, especially on their formation of questions. This body of research suggests that learners need to consciously apprehend the language information and become aware of certain language features in order to internalize such language knowledge (Schmidt, 2001; Van Lier, 2004).

This body of research has focused more on lexical issues than on grammatical forms
(Fujii \& Mackey, 2009; García Mayo \& Pica, 2000; Williams, 1999). Philp, Adams, and Iwashita's (2014) review of research using language related episodes in the examination of the focus of interaction feedback provided by learners during peer talk, also shows that learners paid attention to a wide range of forms; however, lexis tends to receive more attention than grammar, mechanics and most other aspects. Similarly, Philp, Walter, and Basturkmen (2010) used language-related episodes $^{1}$ (LREs) to investigate undergraduate students' attention to form in a foreign language context, and found that the focus of these episodes was placed on lexis rather than grammatical or phonological features.

In short, peer talk has the potential for much language learning to take place. It is "a vital context for learning" and "complements the roles played by the teacher" (Philp et al., 2014 , p. 202) in a language classroom.

\subsection{Peer interaction from sociocultural perspectives}

Complementary to cognitively oriented interaction research are studies based on socio-cultural approaches. While the interactionist perspectives focus on how individual learners learn a language through making input and output more comprehensible during interaction, sociocultural perspectives emphasize interaction itself as the learning process, in which the nature of learning is social rather than individual, and language serves as a mediating tool to jointly construct meaning (Mitchell, Marsden, \& Myles, 2013). Sociocultural theory, which originated from the works of Vygotsky (Vygotsky, 1987, 1978),

1 Language related episodes are instances of dialogue in which students talk about the language they are producing, question their own or others' language use, or correct themselves or others (Swain \& Lapkin, 1998) 
has been widely applied in the field of L2 teaching and learning. Two central concepts of sociocultural theory are the Zone of Proximal Development (ZPD) and scaffolding. The ZPD is now considered a potential learning opportunity for all learners (Wells, 1998), as learners are deemed able to assist one another in language development (Sato \& Ballinger, 2012; Van Lier, 1996, 2004). Scaffolding among learners in language learning has been named in the literature as 'collective scaffolding' (Donato, 1994) and 'collaborative dialogue' (Swain, 2000; Swain \& Lapkin, 1998, 2002), in which learners support one another in solving linguistic problems and/ or co-construct language or knowledge about language. This has been demonstrated by empirical studies on collaborative learning such as those of Donato (1994), Aljaafreh and Lantolf (1994), Ohta (2001), Foster and Ohta (2005), Nassaji and Swain (2000), and Swain and Lapkin (1998).

During peer interaction, not only less proficient learners can benefit, but more capable learners can as well. Through explaining difficult tasks to a less proficient learner, a more capable learner must clarify their ideas by using suitable language; thus improving their language ability (Van Lier, 2004; Watanabe \& Swain, 2007). Empirical evidence also shows that less proficient learners can also support more proficient learners (e.g., Seo \& Kim, 2011; Storch \& Aldosari, 2013). Currently, Vygotskian's "expert" and "novice" terms have now been interpreted in a more flexible way; that is, they can be alternated between learners as claimed by Storch (2002). A review of peer collaborative studies by Swain, Brooks, and Tocalli-Beller (2002) shows that peer collaborative dialogue has a positive impact on L2 learning such as considerable production of the target language. Shima (2008) also found that both more proficient learners and less proficient learners receive benefits from peer assistance, and confirms the claim on the changeable nature of the expert and the novice made by Storch (2002).

In studies adopting a sociocultural lens, the collaborative support and the coconstruction of language knowledge have often been examined through language related episodes (e.g., Fortune, 2005; Swain \& Lapkin, 1998; Watanabe \& Swain, 2007). As such, LREs have been used in peer interaction studies not only to investigate learners' attention paid to language features, but also the collaborative support among learners and the co-construction of language knowledge of the learner.

\subsection{Different aspects of peer interaction}

Previous sections have discussed a variety of aspects of peer talk including the provision of interactional feedback, learners' attention to the target language, output modifications, and collaboration among learners. The affective dimension of peer talk is also an important aspect as affective values can influence learners' learning, especially the motivation to maintain the talk (Philp et al., 2014). Among varied affective factors documented in the literature, attitudes and motivation have been the central foci of research for several decades. Both attitude and motivation are closely related and attitude is even regarded by Gardner (1985) as one component of motivation. Nevertheless, most studies investigating these factors deal with language learners in general, not with language learners during peer interaction specifically. Indeed, learners were positively influenced by those who were co-operative and supportive (Chang, 2010). When learners enjoyed working together in groups, they 
often displayed a "collective orientation to problem solving” (Donato, 1994, p. 40). Therefore, learners' attitudes towards other interlocutors and towards the learning task are worth investigating.

\section{Engagement with language - a potential construct}

\subsection{Student engagement as a multidimensional construct}

The concept of student engagement has become an important notion in education literature, which often refers to the students' behaviour and their psychological connections with schooling or institutionalized learning. It has been extensively researched in varied contexts since it was first introduced over 30 years ago. The important role of student engagement has been highlighted by Christenson, Reschly, and Wylie (2012, p. 817) as it "drives learning ... and can be achieved for all learners". However, there has been little consensus on its definition or its measurement. This concept appears in the literature under a number of different terms including engagement, engagement with school, school engagement, student engagement, and student engagement with school. Nevertheless, even when the same terms are used, researchers propose a range of definitions, causing difficulty in making cross-study comparisons (Fredricks, Blumenfeld, \& Paris, 2004).

Acknowledging the existence of the variety of conceptualizations of engagement, Appleton, Christenson, and Furlong (2008) called for the development of consensus on the operationalized definition of the construct 'student engagement' as well as more reliable measures of this construct. Their metaanalysis of the 19 existing studies suggests that engagement is a multidimensional construct encompassing a range of dimensions. The most often documented dimensions were behavioural and emotional or affective (e.g., Finn, 1989; Marks, 2000; Willms, 2003). The third most common dimension found in the literature is the cognitive (e.g., Fredricks et al., 2004; Jimerson, Campos, \& Greif, 2003). Besides these is a less common model of four dimensions including academic, behavioural, cognitive, and psychological (Reschly \& Christenson, 2006a, 2006b) (see Appleton et al., 2008 for examples of descriptions of engagement).

\subsection{Engagement in second language learning}

Similarly, in the field of language learning, engagement has been recognized as an ideal condition for learning, but the term has been overused with little principled understanding with the exception of Svalberg (2009) who suggested a model of 'engagement with language'(Philp \& Duchesne, 2016).

Most commonly, this concept has often been employed to refer to the involvement and participation of learners in different learning contexts (e.g., Coertze, 2011; Ebe, 2011; Miller, 2010). For example, Miller (2010) described the engagement of adult language learners as their involvement and participation in classroom activities, while Coertze (2011) and Ebe (2011) used the term 'reading engagement' to refer to how learners involve themselves with the reading texts and the reading process. In the context of English as a second language reading engagement in an online environment, Coertze (2011) follows Conrad and Donaldson (2004) in arguing that 'engaged reading' leads to 'engaged learning', and that learning is interactive as during the collaborative learning process, learners actively collaborate with others in constructing the knowledge.

Learner engagement has also been found to be important as it enhances learners' 
communicative competence (Savignon, 2007). Engagement can be achieved through the negotiation of both the meaning of the message and its form (Antón, 1999; Doughty \& Williams, 1998; Lightbown \& Spada, 1990), and when learners are engaged in such negotiations they can express their messages more accurately (Antón, 1999). Also, learners' engagement in communicative tasks in the classroom has been stressed in the research on classroom discourse (Antón, 1999; Peirce, 1995; Van Lier, 2004).

In second language learning literature, there are two forms of learner engagement identified that are closely related to language elements. The first type of engagement is related to language and the second type of engagement is concerned with the learning task and task realization rather than with the language (Ohta, 2001). The former type of engagement refers to the engagement with the language itself (language as an object), and was identified through the analysis of both learners' self-directed speech (i.e., oral language uttered either addressed to the speaker himself or to no one in particular) and discussions about linguistic elements. The latter type focuses on the way learners handle the task instruction and perform the learning tasks. There have been a number of studies examining learners' engagements with tasks (Lin, 2012; Platt \& Brooks, 2002); whereas, there have been few studies which investigated how learners engage with language especially during collaborative talk. Storch (2008) was one of the very few recent scholars to investigate the learners' engagement with language as an object. Storch (2008) has pointed out that the more learners are engaged in the discussion about the language, the more benefits for learning they can gain.
3.3. The emergence of the construct of engagement with language

As previously mentioned, engagement with language as an object was first introduced by Storch (2008), who used this term to refer to the "quality of the learners' metatalk" (p. 98) while learners are performing a text construction task in pairs. Her study focused on the quality of learners' metatalk and its impact on the language learning process. The units of analysis of learner metatalk were language-related episodes. These instances of learner talk show an explicit focus on the target language of learners and their degree of involvement with the discussion about the language. The following extract between students named as $\mathrm{N}$ and $\mathrm{R}$ is taken from Storch (2008) to demonstrate how learners deliberately discussed the meaning of the word 'pension'.

$76 \mathrm{~N}$ : pensions . . . (long pause)

77 R: dictionary3

$78 \mathrm{~N}$ : pensions is the money no? ...

79 R: pension money?

$80 \mathrm{~N}$ : yeah ... when the people retire

81 R: uh-huh

$82 \mathrm{~N}$ : the government also private company

83 R: uh-huh

$84 \mathbf{N}$ : give the money back they

85 R: ok ... I must misunderstand that ... so over half

Storch (2008, p. 101)

In her study, Storch classifies engagement into two levels: elaborate engagement and limited engagement. In elaborate engagement, learners deliberately discussed linguistic items (e.g., asking for clarification, providing 
confirmation); while in limited engagement, learners only stated the language item without any further discussion. Storch's definition of engagement is useful as it has added to our knowledge a new understanding of how learners engage with language as an object of study. However, this conceptualization of engagement with language seems limited when being compared to Svalberg's (2009) concept.

Svalberg's (2009) engagement with language appears to be a broader concept in several respects. Firstly, Svalberg's concept refers to engagement with language both as an object and a medium of communication. Secondly, her definition of engagement shows that this construct encompasses more than just the explicit discussion of language items. Although not explicitly stated by Svalberg as a multidimensional construct, her model of engagement with language actually encompasses multiple interdependent aspects, that is, cognitive, social and affective. More interestingly, Svalberg's (2009) construct of engagement with language aligns with the literature on student engagement in the respect that it does consist of three common dimensions (i.e., cognitive, social and affective), though details of each component are differently defined as Svalberg's concept belongs to the specific field of language teaching and learning. As such, Svalberg's concept of engagement with language reveals the complexity of learners' engagement in language learning (Philp \& Duchesne, 2016) and is "potentially a richer notion" Svalberg $(2009$, p. 243) than that of Storch (2008).

In the development of this construct of engagement with language, Svalberg (2009) followed Ellis's (2004) methodology to interrogate a construct. She compared the new construct with those concepts which appear to be semantically related (i.e., involvement, commitment and motivation). Svalberg's (2009) comparison revealed that the new construct incorporates all the features of these related constructs. In addition, engagement with language has two unique features, that is, 'focused attention' and 'action knowledge' - making knowledge one's own). The focused attention refers to learners' attentional focus on the target language as an object or a means to communicate, and the action knowledge refers to learners' construction of their knowledge as a result of the mental process, but also as a result of "being socially active and taking initiatives" (Svalberg, 2009, p. 246).

The cognitive aspect of engagement centres on learners' alertness, focused attention, and their construction of knowledge about language. For example, learners' learning reflections (e.g., noticing and reflecting on such aspects of language including pronunciation, word meaning and grammatical mechanics) reveal their cognitive engagement. Social engagement, which commonly refers to learners' behaviour in the literature of engagement, is shown through learners' interaction behaviour (i.e., maintaining their interaction), support among learners during the interactive process, and the roles they take up in the conversation (i.e., how they initiate talk, negotiate ideas and accept others). Affective engagement, which is often used to describe positive attitudes of learners towards different aspects of the learning community, in this particular setting refers to learners' attitudes towards the language, the content represented and other interlocutors. A summary of the conceptualization of the construct engagement with language is shown in Figure 1. 


\section{Engagement With Language}

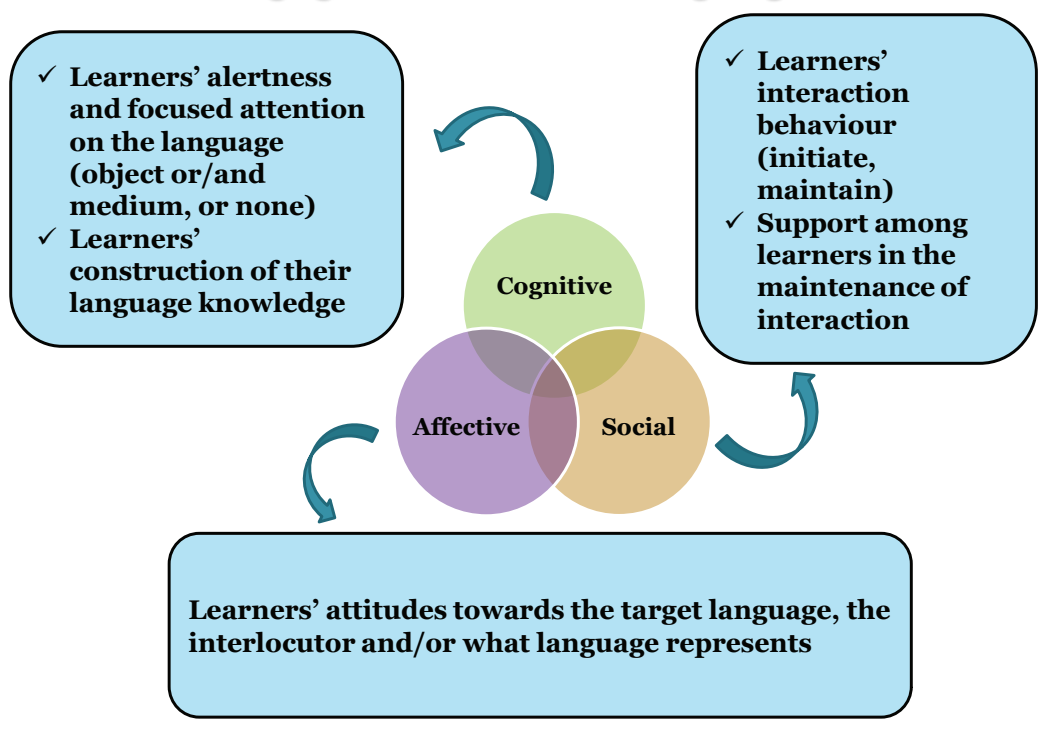

Figure 1. Svalberg's engagement with language

According to Svalberg, these three components of engagement with language are related to one another and the combination of them can enable the description of different aspects of language learning including peer interaction. Apparently, all the above aspects of engagement with language can provide a comprehensive description of peer interaction, covering all its relevant aspects being discussed so far. It might be argued that this construct is too broad; however, this construct seems potentially useful due to its complexity, making possible research which aims to examine a larger number of aspects of language learning such as peer interaction.

This model has been used by a number of researchers including Kearney and Ahn (2013), Baralt, Gurzynski-Weiss, and Kim (2016) and Nguyen (2017). Kearney and Ahn (2013) examined pre-school learners' engagement with language in an 'early world language learning' program. In their study, they use 'engagement with language' episodes as units of analysis. On the one hand, these episodes are comparable to Swain and Lapkin's language-related-episodes in the respect that they are explicit discussions of language use. On the other hand, they went further than that by incorporating more than just what was being said (e.g., paralinguistic features), which is largely based on the criteria provided by Svalberg to identify learners' engagement with language. These criteria are claimed by Kearney and Ahn (2013, p. 331) to be "highly practical and flexible", and that which was proposed by Kearney and Ahn (2013) as 'engagement with language' episodes also provide insights into both the way learners reflect on language aspects and non-verbal cues. Baralt et al. (2016), which compared the engagement of adult Spanish foreign language learners during task-based interaction in either face-to-face classroom interaction or computer-mediated communication, also used language-related episodes as a primary unit of analysis for both cognitive and social engagement with language. Nguyen (2017) draws on the systemic functional approach to 
provide a systematic description of all three aspects of EFL learners' engagement with language during classroom peer interaction.

\section{Conclusion}

This paper has provided detailed discussions of the facilitative role of peer interaction in second language teaching and learning. Complementary to teacher-learner interaction, peer interaction has proved to be an important context for language learning, especially in EFL classrooms where learners mostly engage in interaction with other peers. Learner-learner interaction benefits learners by creating opportunities for them to try out new language, to negotiate for meaning making, and to provide one another with support in the completion of the learning task. This paper has also highlighted different aspects of peer interaction and proposed the construct of engagement with language as a potential for research into second language learning and teaching. This newly emerged multi-dimentional concept is believed to be a "critical step forward in understanding engagement in language learning contexts" (Philp \& Duchesne, 2016, p.62) including group discussions as in this study. Additionally, Svalberg's (2009) list of criteria for identifying learners' engagement with language can be useful for any examinations of this construct. It is expected that, more studies will be conducted to further explore this concept or/and to investigate language learners' engagement with language during peer interaction.

\section{References}

Adams, R. (2007). Do second language learners benefit from interacting with each other? In A Mackey (Ed.), Conversational Interaction in Second Language Acquisition (pp. 29-51). Oxford: Oxford University Press.
Adams, R., Nuevo, A., \& Egi, T. (2011). Explicit and Implicit Feedback, Modified Output, and SLA: Does Explicit and Implicit Feedback Promote Learning and Learner-Learner Interactions? The Modern Language Journal, 95(1), 42-63.

Aljaafreh, A., \& Lantolf, J. P. (1994). Negative Feedback as Regulation and Second Language Learning in the Zone of Proximal Development. The Modern Language Journal, 78(4), 465-483.

Antón, M. (1999). The Discourse of a learnercentered classroom: sociocultural perspectives on teacher-learner interaction in the second-language classroom. The Modern Language Journal, 83(3), 303-318.

Appleton, J. J., Christenson, S. L., \& Furlong, M. J. (2008). Student engagement with school: Critical conceptual and methodological issues of the construct. Psychology in the Schools, 45(5), 369-386.

Baralt, M., Gurzynski-Weiss, L., \& Kim, Y. (2016). Engagement with the language: How examining learners' affective and social engagement explains successful learner-generated attention to form. In M. Sato \& S. Ballinger (Eds.), Peer Interaction and Second Language Learning: Pedagogical potential and research agenda (pp. 209-240). Amsterdam: John Benjamins.

Bruton, A., \& Samuda, V. (1980). Learner and teacher roles in the treatment of oral error in group work. RELC Journal, 11(2), 49-63.

Chang, L. Y.-H. (2010). Group Processes and EFL Learners' Motivation: A Study of Group Dynamics in EFL Classrooms. TESOL Quarterly: A Journal for Teachers of English to Speakers of Other Languages and of Standard English as a Second Dialect, 44(1), 129-154.

Christenson, S. L., Reschly, A. L., \& Wylie, C. (Eds.). (2012). Handbook of research on student engagement: Springer Science \& Business Media.

Coertze, L. (2011). An investigation of ESL students' reading engagement and language output in selected online environments. (M.A.), Iowa State University. ProQuest Dissertations \& Theses A\&I database.

Conrad, R., \& Donaldson, J. A. (2004). Engaging the online learner: Activities and resources for creative learning. San Francisco, CA: Jossey-Bass.

Donato, R. (1994). Collective scaffolding in second language learning. In J. P. Lantolf \& G. Appel (Eds.), Vygotskian approaches to second language research (pp. 33-56). New Jersey: Ablex.

Doughty, C., \& Pica, T. (1986). “Information gap” tasks: Do they facilitate second language acquisition? TESOL Quarterly, 305-325.

Doughty, C., \& Williams, J. (1998). Focus on form in classroom second language acquisition. Cambridge: Cambridge University Press. 
Ebe, A. E. (2011). Culturally relevant books: Bridges to reading engagement for English language learners. Insights on Learning Disabilities: From Prevailing Theories to Validated Practices, 8(2), 31-45.

Egi, T. (2007). Recasts, learners' interpretations, and L2 development. Conversational interaction in second language acquisition: A collection of empirical studies, 249-267.

Ellis, R. (2004). The definition and measurement of L2 explicit knowledge. Language Learning, 54(2), 227-275.

Ferguson, C. A. (1971). Absence of copula and the notion of simplicity: A study of normal speech, baby talk, foreigner talk and pidgins. In D. Hymes (Ed.), Pidginization and creolization of languages (pp. 117-140). Cambridge: Cambridge University Press.

Ferguson, C. A. (1975). Toward a Characterization of English Foreigner Talk. Anthropological Linguistics, 17(1), 1-14.

Fernández Dobao, A. (2012). Collaborative Dialogue in Learner-Learner and Learner-Native Speaker Interaction. Applied Linguistics, 33(3), 229-256.

Finn, J. D. (1989). Withdrawing From School. Review of Educational Research, 59(2), 117-142.

Fortune, A. (2005). Learners' use of metalanguage in collaborative form-focused L2 output tasks. Language Awareness, 14(1), 21-38.

Foster, P., \& Ohta, A. S. (2005). Negotiation for meaning and peer assistance in second language classrooms. Applied Linguistics, 26(3), 402-430.

Fredricks, J. A., Blumenfeld, P. C., \& Paris, A. H. (2004). School Engagement: Potential of the Concept, State of the Evidence. Review of Educational Research, 74(1), 59-109.

Fujii, A., \& Mackey, A. Y. (2009). Interactional feedback in learner-learner interactions in a taskbased EFL classroom. International Review of Applied Linguistics in Language Teaching, 47(3-4), 267-301.

García Mayo, M. d. P., \& Pica, T. (2000). L2 learner interaction in a foreign language setting: Are learning needs addressed? International Review of Applied Linguistics in Language Teaching, 38(1), 35-58.

Gardner, R. C. (1985). Social psychology and second language learning: The role of attitudes and motivation. London: Edward Arnold.

Gass, S. M., \& Mackey, A. (2007). Input, Interaction, and output in second language acquisition. In B. VanPatten \& J. Williams (Eds.), Theories in second language acquisition: An introduction (pp. 175200). Mahwah: Lawrence Erlbaum.

Hatch, E. (1978). Discourse analysis and second language acquisition. In E Hatch (Ed.), Second Language Acquisition: A book of readings (pp. 401435). Rowley, Ma: Newbury House.
Jimerson, S. R., Campos, E., \& Greif, J. L. (2003). Toward an Understanding of Definitions and Measures of School Engagement and Related Terms. California School Psychologist, 8, 7-27.

Kang, K. I. (2015). Peer Interaction: A Compromise or a Necessity? APPLE Award Winning Papers in $T E S O L \& A L, 15(2)$.

Kearney, E., \& Ahn, S.-Y. (2013). Preschool world language learners' engagement with language: what are the possibilities? Language Awareness, 23(4), 319-333.

Lightbown, P. M., \& Spada, N. (1990). Focus-onForm and Corrective Feedback in Communicative Language Teaching. Studies in Second Language Acquisition, 12(04), 429-448.

Lin, T.-J. (2012). Student engagement and motivation in the foreign language classroom. (PhD), Washington State University, Washington.

Long, M. H., Adams, L., McLean, M., \& Castanos, F. (1976). Doing things with words: Verbal interaction in lockstep and small group classroom interactions. In J. Fanselow \& R. Crymes (Eds.), On TESOL 76 (pp. 137-153). Washington DC: TESOL.

Mackey, A. (2006). Feedback, noticing and instructed second language learning. Applied Linguistics, 27(3), 405-430.

Mackey, A. (Ed.) (2007). Conversational Interaction in Second Language Acquisition. Oxford: Oxford University Press.

Mackey, A., Abbuhl, R., \& Gass, S. M. (2012). Interactionist approach. In S M Gass \& A. Mackey (Eds.), The Routledge Handbook of Second Language Acquisition (pp. 7-23). New York: Routledge.

Mackey, A., Oliver, R., \& Leeman, J. (2003). Interactional Input and The Incorporation of Feedback: An Exploration of NS-NNS and NNSNNS Adult and Child Dyads. Language Learning, 53(1), 35-66.

Mackey, A., Philp, J., Egi, T., Fujii, A., \& Tatsumi, T. (2002). Individual differences in working memory, noticing of interactional feedback, and L2 development. In P Robinson (Ed.), Individual differences and instructed language learning (pp. 181-210). Amsterdam: John Benjamins.

Marks, H. M. (2000). Student engagement in instructional activity: Patterns in the elementary, middle, and high school years. American Educational Research Journal, 37(1), 153-184.

McDonough, K. (2004). Learner-learner interaction during pair and small group activities in a Thai EFL context. System, 32(2), 207-224.

Miller, S. F. (2010). Promoting Learner Engagement when Working with Adult English Language Learners. CAELA Network Brief, 1-8. 
Mitchell, R., Marsden, E., \& Myles, F. (2013). Second Language Learning Theories. London: Routledge.

Nassaji, H., \& Swain, M. (2000). A Vygotskian perspective on corrective feedback in L2: The effect of random versus negotiated help on the learning of English articles Language Awareness, 9(1), 34-51.

Nguyen, T. H. (2017). EFL Vietnamese learners' engagement with English language during oral classroom peer interaction. $\mathrm{PhD}$ Thesis. University of Wollongong.

Ohta, A. S. (2001). Second Language Acquisition Processes in the Classroom Setting: Learning Japanese. Mahwah, NJ: Lawrence.

Peirce, B. N. (1995). Social identity, investment, and language learning. TESOL Quarterly, 29(1), 9-31.

Philp, J. (2003). Constraints on "noticing the gap": nonnative speakers' noticing of recasts in NS-NNS interaction. Studies in Second Language Acquisition, 25(1), 99-126.

Philp, J., Adams, R., \& Iwashita, N. (2014). Peer interaction and second language learning. New York: Routledge.

Philp, J., \& Duchesne, S. (2016). Exploring Engagement in Tasks in the Language Classroom. Annual Review of Applied Linguistics, 36, 50-72.

Philp, J., \& Iwashita, N. (2013). Talking, tuning in and noticing: exploring the benefits of output in task-based peer interaction. Language Awareness, 22(4), 353-370.

Philp, J., Walter, S., \& Basturkmen, H. (2010). Peer interaction in the foreign language classroom: what factors foster a focus on form? Language Awareness, 19(4), 261-279.

Platt, E., \& Brooks, F. B. (2002). Task Engagement: A Turning Point in Foreign Language Development. Language Learning, 52(2), 365-400.

Reschly, A. L., \& Christenson, S. L. (2006a). Research leading to a predictive model of dropout and completion among students with mild disabilities and the role of student engagement. Remedial and Special Education, 27(5), 276-292.

Reschly, A. L., \& Christenson, S. L. (2006b). Promoting successful school completion. In G. Bear \& K. Minke (Eds.), Children's needs-III: Development, prevention, and intervention (pp. 103 - 113). Bethesda, MD: National Association of School Psychologists.

Rulon, K., \& McCreary, J. (Eds.). (1986). Negotiation of content: Teacher-fronted and small-group interaction. Rowley, MA: Newbury House.

Sato, M. (2007). Social Relationships in Conversational Interaction: Comparison of Learner-LearnerNS Dyads. JALT journal / Japan Association of Language Teachers, 29(2), 183-208.

Sato, M., \& Ballinger, S. (2012). Raising language awareness in peer interaction: a cross-context, cross- methodology examination. Language Awareness, 21(1-2), 157-179.

Sato, M., \& Ballinger, S. (2016). Introduction: Understanding peer interaction, research synthesis and directions. In M. Sato \& S. Ballinger (Eds.), Peer Interaction and Second Language Learning: Pedagogical potential and research agenda (pp. 1-30). Amsterdam: John Benjamins.

Sato, M., \& Lyster, R. (2007). Modified output of Japanese EFL learners: Variable effects of interlocutor versus feedback types. In A Mackey (Ed.), Conversational Interaction in Second Language Acquisition, Alison Mackey (ed.), . (pp. 123-142). Oxford: Oxford University Press.

Sato, M., \& Lyster, R. (2012). Peer interaction and corrective feedback for accuracy and fluency development. Studies in Second Language Acquisition, 34(4), 591-626.

Savignon, S. J. (2007). Beyond communicative language teaching: What's ahead? Journal of Pragmatics, 39(1), 207-220.

Schmidt, R. (2001). Attention. In P Robinson (Ed.), Cognition and second language instruction (pp. 3-32). New York: Cambridge University Press.

Seo, H.-S., \& Kim, T.-Y. (2011). Collaborative dialogues and L2 learning: Korean junior high school students' pair-work in English composition. Korean Journal of Applied Linguistics, 27(1), 345-380.

Shima, C. (2008). Fluidity of Peer Interaction in a Japanese Language Classroom. Electronic Journal of Foreign Language Teaching, 5(1), 126-139.

Storch, N. (2002). Patterns of interaction in ESL pair work. Language Learning, 52(1), 119-158.

Storch, N. (2008). Metatalk in a pair work activity: Level of engagement and implications for language development. Language Awareness, 17(2), 95-114.

Storch, N., \& Aldosari, A. (2013). Pairing learners in pair work activity. Language Teaching Research, $17,31-48$.

Svalberg, A. M. L. (2009). Engagement with language: interrogating a construct. Language Awareness, 18(3-4), 242-258.

Swain, M. (2000). The output hypothesis and beyond: Mediating acquisition through collaborative dialogue. In J Lantolf (Ed.), Sociocultural theory and second sanguage searning. Oxford: Oxford University Press.

Swain, M., Brooks, L., \& Tocalli-Beller, A. (2002). Peer-peer dialogue as a means of second language learning. Annual Review of Applied Linguistics, 22, 171-185.

Swain, M., \& Lapkin, S. (1998). Interaction and second language learning: Two adolescent French immersion students working together. The Modern Language Journal, 82(3), 320-337. 
Swain, M., \& Lapkin, S. (2002). Talking it through: Two French immersion learners' response to reformulation. International Journal of Educational Research, 37(3-4), 285-304.

Van Lier, L. (1996). Interaction in the language curriculum: Awareness, autonomy and authenticity. London: Longman.

Van Lier, L. (2004). The Ecology and Semiotics of Language Learning: A social Cultural Perspective. New York: Kluwer Academic Publishers.

Vygotsky, L. S. (1987). Thinking and speech (N. Minick, Trans.). In RW Rieber \& AS Carton (Eds.), The collected works of L.S. Vygotsky. New York: Plenum Press.

Vygotsky, L. S. (Ed.) (1978). Mind and Society: The Development of Higher Mental Processes. Cambridge, Mass: Harvard University Press.

Wagner-Gough, J., \& Hatch, E. (1975). The importance of input data in second language acquisition studies. Language Learning, 25(2), 297-308.

Watanabe, Y., \& Swain, M. (2007). Effects of proficiency differences and patterns of pair interaction on second language learning: collaborative dialogue between adult ESL learners. Language Teaching Research, 11(2), 121-142.

Wells, G. (1998). Using L1 to master L2: a response to Anton and DiCamilla's 'socio-cognitive functions of L1. Canadian Modern Language Review, 54(3), 343-353.

Williams, J. (1999). Learner-generated attention to form. Language Learning, 49(4), 583-625.

Willms, J. D. (2003). Student engagement at school: $A$ sense of belonging and participation. Paris: Organisation for Economic Co-Operation and Development.

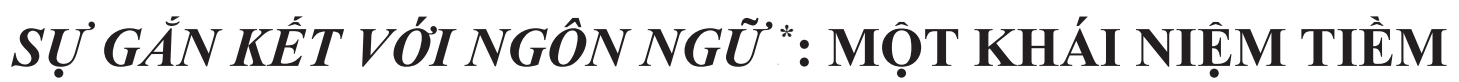 NĂNG CHO CÁC NGHIÊN CỬU VỀ VIÊC TƯƠNG TÁC GIŨ๋A NHŨ'NG NGƯỜI HỌC NGÔN NGŨ๋
}

\author{
Nguyễn Thu Hiền \\ Khoa Su phạm tiếng Anh, \\ Truòng Đại học Ngoại ngũ - Đại học Quốc gia Hà Nội, \\ Đương Phạm Văn Đồng, Cầu Giấy, Hà Nội, Việt Nam
}

Tóm tắt: Người học ngôn ngữ thường sử dụng nhiều thời gian trong lớp học để tương tác với nhau. Điều này đúng với cả lớp học ngôn ngữ thứ hai cũng như ngoại ngữ. Việc tương tác giữa những người học ngày càng được xem là một ngữ cảnh lý tưởng cho việc học ngôn ngữ. Vì vậy, ngày càng có nhiều nghiên cứu về các khía cạnh của việc tương tác này. Các nghiên cứu trước đây đã mang lại những kiến thức hay về nhiều khía cạnh của sự tương tác giữa những người học, ví dụ như việc cung cấp phản hồi tương tác; việc sản sinh ngôn ngữ; việc sửa đổi ngôn ngữ trong quá trình đàm phán khi học; việc chú ý đến cấu trúc, tù vựng, phát âm; hay việc hợp tác giữa những người học trong quá trình học ngôn ngữ. Tuy nhiên, vẫn chưa có một khái niệm nào giúp chúng ta nghiên cứu được nhiều khía cạnh của việc tương tác này. Bài viết này đề xuất việc sử dụng khái niệm của Svalberg (2009) có tên là "sự gắn kết với ngôn ngư" cho các nghiên cứu về việc tương tác giữa những người học ngôn ngữ vì khái niệm này bao gồm được cả 3 mảng lớn của việc tương tác; đó là nhận thức, xã hội và cảm xúc.

Tù khóa: sự gắn kết với ngôn ngữ, tương tác giữa những người học, nhận thức, xã hội, cảm xúc

\footnotetext{
* Engagement with language
} 